\title{
PENGARUH FAKTOR INTERNAL DAN EKSTERNAL DALAM KEBIJAKAN KOMPENSASI
}

\author{
Willy Candra; Zulyana Rahma.H; Sugianto; Felicia Ayu \\ weareonefamily351@gmail.com
}

Kompensasi adalah segala sesuatu yang diterima karyawan sebagai balas jasa atas kerja mereka di suatu organisasi. Kompensasi biasanya terdiri dari kompensasi langsung dan tidak langsung. Kompensasi langsung meliputi gaji pokok atau upah/wages dan gaji variabel/insentif, sedangkan kompensasi tidak langsung berupa tunjangan-tunjangan/benefits yang diberikan oleh organisasi kepada karyawannya. Tujuan pemberian kompensasi antara lain untuk menarik orangorang yang berkualitas agar bergabung ke dalam organisasi, untuk memotivasi anggota organisasi agar lebih produktif, dan untuk mempertahankan karyawan agar tetap bekerja di dalam organisasi.

Penentuan kompensasi dipengaruhi oleh faktor internal dan eksternal, seperti penawaran dan permintaan tenaga kerja, serikat pekerja, peraturan pemerintah, kemampuan organisasi dan sebagainya. Keadilan merupakan salah satu faktor penting dalam menentukan kompensasi, baik keadilan internal maupun eksternal. Untuk menjamin keadilan internal organisasi dapat melakukan evaluasi pekerjaan, sedangkan untuk memastikan keadilan eksternal dapat dilakukan dengan survei gaji/upah. Sebuah organisasi membutuhkan dan harus memperoleh personil yang berkualitas, dan perusahaan menyusun kebijakan kompensasi untuk memotivasi kepada karyawan agar lebih semangat bekerja, dan mendapatkan rasa kenyamanan dan keamanan dari sebuah organisasi tempat setaip karyawan bekerja.

Karyawan akan merasa dihargai atas kerja kerasnya selama bekerja di beri kompensasi yang lebih. Setiap organisai memberikan kompensasi yang lebih kepada karyawan agar karyawan bekerja lebih semangat lagi untuk perusahaannya. Jika kompensasi berjalan lancar maka karyawan juga tidak menunggak pekerjaannya, sebaliknya jika kompensasi tidak berjalan lancar maka karyawan juga menjadi malas dan bekerja apa adanya saja.

Kompensasi sangat penting bagi para karyawan maka dari itu Manajemen kinerja haruslah dipandang sebagai suatu sistem yang beroperasi secara luas agar hasil dari manajemen kinerja maksimal. Sistem adalah sekumpulan dari elemen-elemen yang terpadu dan memiliki ikatan 
khusus yang saling beriteraksi untuk mencapai tujuan tertentu. Sistem adalah bagian-bagian yang beroperasi bersama-sama untuk mencapai tujuan. Sistem terdiri atas subsistem-subsistem. Sistem adalah subsistem-subsistem yang saling berinteraksi secara sinerji untuk mencapai tujuan secara efektif dan efisien. Sistem ialah subsistem-subsistem yang saling berinteraksi, berkorelasi, dan berdependensi yang membentuk suatu kesatuan utuh melebihi jika subsistem-subsistem bekerja sendiri-sendiri (sinergik).

Proses dalam sistem manajemen kinerja bukanlah sebuah proses yang bersifat linier atau proses garis lurus saja. Bayangkanlah sebuah tangga rumah. Kalau kita menaiki tangga, kita melangkah ke anak tangga pertama, kemudian yang selanjutnya, dan seterusnya. Sekali kita sudah mencapai anak tangga kelima, biasanya kita tidak akan melompat kembali ke anak tangga pertama. Itulah yang dinamakan proses garis lurus. Kita mulai dengan langkah A, melanjutkan ke langkah B, dan kemudian langkah $\mathrm{C}$, dan seterusnya. Manajemen kinerja tidak seperti garis lurus atau linier. Dalam manajemen kinerja, kita mungkin akan mulai dengan langkah A, pindah ke langkah B, dan kemudian kembali ke langkah A. Kadang kadang juga harus meletakkan kaki di dua tempat sekaligus.

Mengapa? Karena proses dalam manajemen kinerja bukanlah sebuah proses yang linier seperti menaiki tangga tadi. Manajemen kinerja merupakan sebuah proses yang tidak linier. Proses manajemen kinerja dibahas secara rinci dalam mekanisme perancangan sistem manajemen kinerja. bila manajemen kinerja dilaksanakan secara buruk. Bahwa salah satu alasan utama mengapa banyak manajemen kinerja gagal adalah karena upaya tersebut sama sekali tidak dihubungkan dengan kesuksesan kerja, peningkatan kinerja, pengembangan diri karyawan, sasaran organisasi ataupun bagian penting lainnya dari organisasi.

Jadi, kita perlu memahami bahwa manajemen kinerja adalah sebagai suatu sistem. Sebagai suatu sistem, manajemen kinerja harus berhubungan dengan fungsi-fungsi penting lain lain pada organisasi seperti kesuksesan kerja, peningkatan kinerja, pengembangan diri karyawan, dan sasaran organisasi. Semakin baik kita merangkaikan suatu sistem manajemen kinerja dengan halhal lain yang harus dilakukan organisasi, semakin besar kemungkinan orang memahami bahwa hal ini mempunyai manfaat yang penting. Selain itu, kita harus memasukkan seluruh komponen sistem manajemen kinerja. Jika kita melupakan satu atau dua bagian, maka sistem tidak akan berjalan lancar. 
Pemberian kompensasi tujuan nya adalah untuk menarik orang yang berkualitas dalam organisasi. Agar karyawan dapat terus bekerja di perusahaan atau organisasi, organisasi harus memotivasi anggota dan beri inovasi agar semangat. Yang diharapkan kompensasi adalah agar dapat terciptanya budaya kerja yang kondusif. Apabila suatu organisasi ingin meningkatkan kualitasnya.

1. Apabila terjadi perubahan intern organisasi :

- Adanya pemimpin atau pejabat baru yang membawa aturan dan harapan baru.

- Perubahan teknologi.

2. Apabila terjadi perubahan di luar organisasi (faktor lingkungan).

- Terjadinya perubahan karena teknologi baru yang digunakan secara luas.

- Terjadi perubahan organisasi sebagai dampak dari kerja sama dengan pihak luar.

Salah satu contoh pemberian kompensasi adalah didalam organisasi dimana tempat saya bekerja. Di organisasi ini para karyawan diberikan dua jenis kompensasi yaitu kompensasi financial dan kompensasi non financial. Kompensasi financial yang didapat berupa gaji, uang cuti, biaya makan, biaya transportasi, serta asuransi. Kompensasi non finansial berupa kenyamanan lingkungan kerja, keamanan tempat kerja sehingga saya menjadi semangat untuk bekerja dan semangat melakukan tugas dan kewajiban yang saya terima dari organisasi tempat saya bekerja.

Knowledge Management juga sangat berpengaruh pada pemberian kompensasi terhadap Kinerja Karyawan. Knowledge management mempengaruhi setiap kinerja yang dikerjakan oleh setiap karyawan yang disebabkan oleh pemberian kompensasi yang di atur sesuai dengan konsep knowledge management. Maka dari itu knowledge management sangat mempengaruhi setiap organisasi dalam pemberian kompensasi. (Sundiman, 2017)

\section{References}

Sundiman, D. (2017). Human Resource Management in the Enhancement Processes of Knowledge Management. Binus Business Review, 8(3), 167-173. 